\title{
Restoration of Normal Membrane Stability to Unstable Protein 4.1-deficient Erythrocyte Membranes by Incorporation of Purified Protein 4.1
}

\author{
Yuichi Takakuwa, Gil Tchernia, Mary Rossi, Mohamed Benabadji, and Narla Mohandas \\ Department of Laboratory Medicine and Cancer Research Institute, University of California, San Francisco, California 94143; University \\ of Paris, Hôpital Bicetre, Kremlin Bicetre, France; and Centre Algerien de Transfusion Sanguine, Hôpital Mustafa, Alger
}

\begin{abstract}
Protein 4.1, a principal component of the erythrocyte membrane skeleton, is thought to be important in regulating membrane stability through its interaction with spectrin and actin. A key role for protein 4.1 has been indicated in studies in which deficiency of this protein was shown to result in marked instability of the membrane. In order to obtain direct evidence for the functional role of protein 4.1, we reconstituted protein 4.1-deficient membranes with purified protein 4.1 and showed restoration of membrane stability. Erythrocyte membranes totally and partially deficient in protein 4.1 were reconstituted by exchange hemolysis with various concentrations of purified protein 4.1, and their stability measured using an ektacytometer. Native erythrocyte membranes totally deficient in protein 4.1 were markedly unstable, while those partially deficient had intermediate reductions in membrane stability. Reconstitution with increasing concentrations of purified protein 4.1 resulted in progressive restoration of membrane stability. Near-normal membrane stability could be restored to both totally and partially protein 4.1-deficient membranes. In contrast, the addition of protein 4.1 to resealed membranes did not improve membrane stability. This implies that the added protein 4.1 must have access to the cell interior in order to affect membrane stability. Furthermore, in control experiments, the addition of protein 4.1 to normal membranes did not increase their stability. Also, the addition of purified spectrin and human serum albumin during resealing did not improve stability of protein 4.1-deficient membranes. These results provide direct evidence for the crucial role of protein 4.1 in regulating erythrocyte membrane stability.
\end{abstract}

\section{Introduction}

Recent biochemical studies have shown that spectrin, protein 4.1, and actin form a skeletal protein network that underlies the inner surface of the erythrocyte membrane (1-4). This network is thought to be important in regulating such membrane functions as deformability and stability $(5,6)$. Support for this hypothesis has been derived from studies of various pathologic erythrocytes in which altered membrane stability has been related to defects in the various skeletal proteins and their interactions (7-13).

Address correspondence to Dr. Mohandas, Cancer Research Institute M-1282, University of California, San Francisco, CA 94143.

Received for publication 12 September 1985 and in revised form 21 January 1986

J. Clin. Invest.

(c) The American Society for Clinical Investigation, Inc. 0021-9738/86/07/0080/06 \$1.00

Volume 78 , July $1986,80-85$
An important function for protein 4.1 was indicated in studies of protein 4.1-deficient erythrocytes from a family of patients with hemolytic anemia $(9,14)$. In these studies, the erythrocyte membranes totally deficient in protein 4.1 showed marked reduction in membrane stability, while membranes partially deficient in this protein showed an intermediate reduction in membrane stability. A study of erythrocytes from another family in which a qualitative defect in the association of protein 4.1 and spectrin was documented also showed a reduction in membrane stability (15). These studies provided strong indirect evidence of protein 4.1's probable importance in maintaining erythrocyte membrane stability.

To obtain direct evidence for a crucial role of protein 4.1 in maintaining membrane stability, we incorporated purified protein 4.1 obtained from normal erythrocytes into protein 4.1deficient membranes. Purified protein 4.1 is a globular protein that migrates as two major polypeptides of 80,000 and 78,000 molecular wt (mol wt) when analyzed on sodium dodecyl sulfatepolyacrylamide gel electrophoresis (SDS-PAGE) ${ }^{1}(16-18)$. These two polypeptides, referred to as protein $4.1 \mathrm{a}$ and $4.1 \mathrm{~b}$, are thought to bind to spectrin with equal efficiency (18) and also to promote spectrin-actin interaction (19-21). When the purified normal protein 4.1 was incorporated into protein 4.1-deficient membranes by exchange hemolysis (22), the stability of these membranes was restored to near-normal values, thus providing direct evidence that protein 4.1 is essential for normal membrane stability.

\section{Methods}

Materials. Whole blood was obtained from a previously studied Algerian family in whom we found elliptocytosis associated with protein 4.1 deficiency (9). The blood was collected into acid citrate dextrose, transported from Algeria to San Francisco, stored at $4^{\circ} \mathrm{C}$, and used within $4 \mathrm{~d}$. Protein 4.1 was purified from normal erythrocytes by the method of Tyler et al. (17), dialyzed against the hypotonic sodium phosphate buffer ( $\mathrm{pH} \mathrm{7.4,}$ $40 \mathrm{mosmol} / \mathrm{kg}$ ), and used within $4 \mathrm{~d}$. Spectrin dimer was purified from normal erythrocytes by the method of Tyler et al. (23). Human serum albumin was obtained from Sigma Chemical Co., St. Louis, MO.

Preparation of resealed ghosts and incorporation of purified protein 4.1 into the ghosts. Erythrocytes were washed with the isotonic sodium

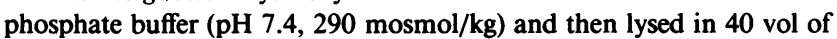
the ice-cold sodium phosphate buffer ( $\mathrm{pH} \mathrm{7.4,} 40 \mathrm{mosmol} / \mathrm{kg}$ ). The membranes were collected by centrifugation at $39,000 \mathrm{~g}$ for $2 \mathrm{~min}$ at $0^{\circ} \mathrm{C}$. To restore isotonicity, a small volume of the mixture of $\mathrm{KCl}, \mathrm{MgCl}_{2}$, and dithiothreitol (DTT) was added to the membrane suspension, giving a final concentration of $100 \mathrm{mM} \mathrm{KCl}, 1 \mathrm{mM} \mathrm{MgCl}$, and $1 \mathrm{mM}$ DTT. The ghost suspension was then incubated at $37^{\circ} \mathrm{C}$ for $60 \mathrm{~min}$ to allow the ghosts to reseal.

1. Abbreviations used in this paper: DI, deformability index; DTT, dithiothreitol; SDS-PAGE, sodium dodecyl sulfate-polyacrylamide gel electrophoresis. 
To incorporate purified protein 4.1 into the ghosts, we modified the technique of exchange hemolysis described by Clark and Shohet (22). After lysis, membranes were harvested. $0.5 \mathrm{ml}$ of purified protein 4.1 solution of a defined concentration was added to $0.4 \mathrm{ml}$ of packed ghosts. The mixture was gently stirred at $0^{\circ} \mathrm{C}$ for $20 \mathrm{~min}$. The membranes were subsequently resealed by the addition of $0.1 \mathrm{ml}$ of the mixture of $\mathrm{KCl}$, $\mathrm{MgCl}_{2}$, and DTT to restore isotonicity as described above.

SDS-PAGE. Membrane proteins were analyzed by SDS-PAGE using the discontinuous buffer system of Laemmli (24). We utilized $1.5 \mathrm{~mm}$ thick slab gels composed of a separating gel of $7 \%$ acrylamide and a stacking gel of $3 \%$ acrylamide. After electrophoresis, proteins on gels were stained with Coomassie Blue. To quantitate the amount of protein 4.1, the gels were dried and analyzed with the densitometer (DU-7; Beckman Instruments, Inc., Palo Alto, CA). Western blot analysis with affinity-purified anti-protein $4.1 \mathrm{IgG}$ was used to establish the identity of polypeptides that are immunologically related to protein 4.1 (25).

Measurement of membrane stability. The resealed ghost samples were suspended in dextran $(40,000 \mathrm{~mol} \mathrm{wt}, 35 \% \mathrm{wt} / \mathrm{vol})$ and examined by the ektacytometer, a laser diffraction method described previously $(15,26)$. In brief, suspended ghosts were subjected to a constant high shear stress of $750 \mathrm{dyne} / \mathrm{cm}^{2}$ and the change in their laser diffraction pattern was measured by recording a signal designated as the deformability index (DI) as a function of time. The DI provides a measure of the ellipticity of the deforming ghosts in the flow field. When the shear stress is first applied, ghosts are deformed into ellipsoids and produce a narrow elliptical pattern that generates a high value of DI. With time, as the ghosts are unable to withstand the large value of applied shear stress, they begin to fragment. This loss of membrane surface as a consequence of fragmentation results in decreasing DI values. The rate at which the DI decreases is a measure of the rate of membrane fragmentation, and hence provides us with a quantitative measure of membrane stability.

\section{Results}

Unstable membranes of protein 4.1-deficient erythrocytes from patients with hereditary elliptocytosis. Membrane protein composition of erythrocytes from various family members of the Algerian family previously studied was reanalyzed. Membranes totally deficient in protein 4.1 and partially deficient in protein 4.1 , as well as normal membranes, are shown in Fig. 1. The Coomassie Blue-stained gels showed absence of protein 4.1 in totally deficient membranes and $\sim 50 \%$ reduction in partially deficient membranes (lane 1). Western blot analysis using affinity-purified anti-protein $4.1 \mathrm{IgG}$ showed complete absence of protein 4.1 in totally deficient membranes (lane 2 ). This data implies that no intact protein 4.1 or protein 4.1 degradation products are present in totally deficient membranes.

Ektacytometric measurements showed marked and intermediate reductions in mechanical stability of membranes totally and partially deficient in protein 4.1 , respectively (Fig. 2). The maximum DI value attained by ghosts prepared from erythrocytes with a total deficiency of protein 4.1 was lower than that of ghosts prepared from normal cells. This is a reflection of the reduced surface area of these cells due to prior in vivo fragmentation.

Restoration of membrane stability after reconstitution of total protein 4.1-deficient erythrocytes. The effect of increasing the concentration of purified protein 4.1 used during membrane reconstitution on mechanical stability of protein 4.1-deficient membranes is shown in Fig. $3 A$. It is evident that the DI signal decayed much more slowly after reconstitution of the membranes with protein 4.1. With increasing amounts of added protein 4.1, the onset of the decay was delayed and the time taken to reach a fractional decline was prolonged, indicating that membrane

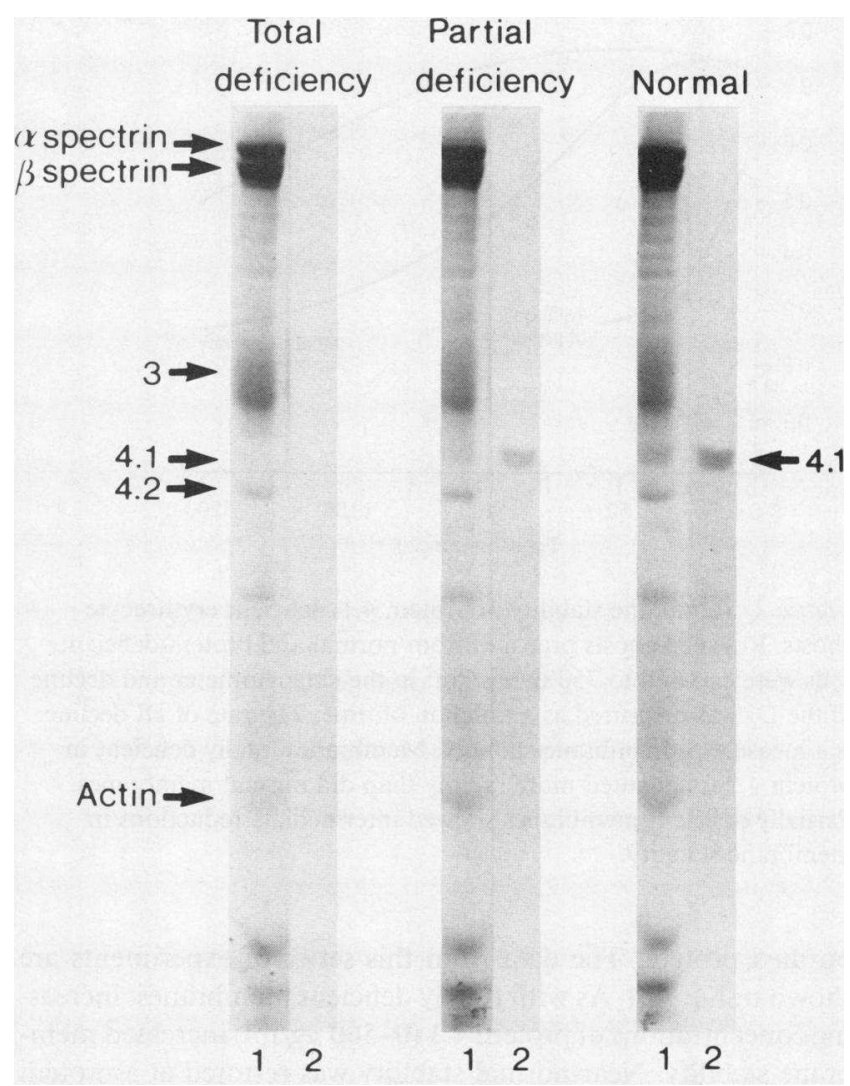

Figure 1. SDS-PAGE analysis of protein 4.1-deficient erythrocyte membranes. Membranes prepared from erythrocytes totally deficient in protein 4.1, partially deficient in protein 4.1, and normal membranes were analyzed on $7 \%$ gels using the Laemmli gradient system (lanes marked 1), and on Western blots with affinity-purified anti-protein $4.1 \mathrm{IgG}$ (lanes marked 2). Note that in comparison to normal membranes, membranes with partial deficiency have reduced amounts of protein 4.1. Western blot analysis showed complete absence of protein 4.1 in totally deficient membranes.

stability was being restored by the association of protein 4.1 with the membrane. Progressive increases in membrane stability can be seen up to a concentration of $560 \mu \mathrm{g} / \mathrm{ml}$ of added protein 4.1. Further increases in protein 4.1 concentration had little further effect on membrane stability. Varying incubation time from 30 to $90 \mathrm{~min}$ during resealing at $37^{\circ} \mathrm{C}$ in the presence of protein 4.1 did not alter membrane response (data not shown). We chose a 60 -min incubation time for all subsequent membrane reconstitution experiments.

To establish that entrapment of protein 4.1 in the ghost is essential to restore membrane stability, we performed experiments in which protein 4.1 was added to resealed ghosts and incubated at $37^{\circ} \mathrm{C}$ for an additional $60 \mathrm{~min}$. This maneuver allowed for protein 4.1 to have access only to the outer surface of the membrane. As shown in Fig. $3 \mathrm{~B}$, addition of purified protein 4.1 at concentrations up to $930 \mu \mathrm{g} / \mathrm{ml}$ did not have any ameliorating effect on membrane stability. These data imply that membrane stability can be restored only when protein 4.1 has access to the inside of the ghost.

Restoration of membrane stability after reconstitution of partial protein 4.1-deficient erythrocytes. Additional evidence for the effects of protein 4.1 on membrane stability was obtained by reconstituting partially protein 4.1 -deficient membranes with 


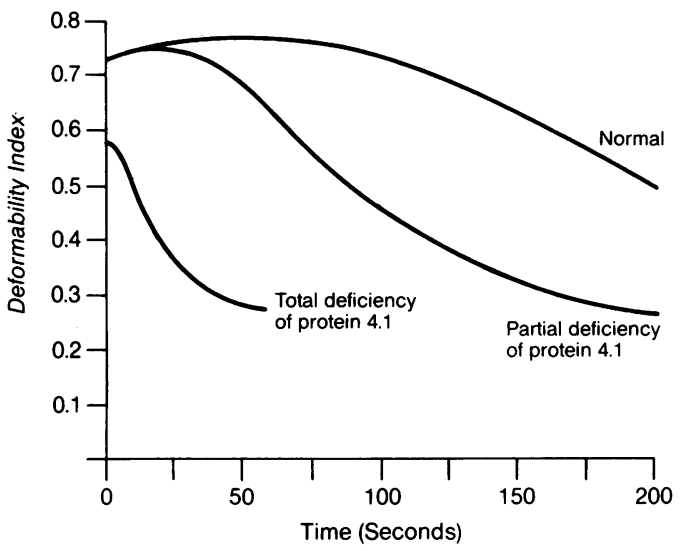

Figure 2. Membrane stability of protein 4.1-deficient erythrocyte ghosts. Resealed ghosts prepared from normal and protein-deficient cells were exposed to 750 dynes $/ \mathrm{cm}^{2}$ in the ektacytometer and decline of the DI was measured as a function of time. The rate of DI decline is a measure of membrane stability. Membranes totally deficient in protein 4.1 fragmented more rapidly than did normal membranes. Partially deficient membranes showed intermediate reductions in membrane stability.

purified protein. The data from this series of experiments are shown in Fig. $4 \mathrm{~A}$. As with totally deficient membranes, increasing concentrations of protein $4.1(0-560 \mu \mathrm{g} / \mathrm{ml})$ increased membrane stability. Near-normal stability was restored at a protein concentration of $560 \mu \mathrm{g} / \mathrm{ml}$. Addition of protein 4.1 to resealed membranes, which allows access only to the outer surface of membrane, did not improve membrane stability (Fig. $4 \mathrm{~B}$ ), a result similar to that obtained with membranes that are totally deficient in protein 4.1. These observations provide further support to our thesis that membrane stability can be restored only when protein 4.1 has access to the inside of the cell.

Membrane stability is unaltered by nonspecifically bound protein 4.1 and by unbound protein 4.1. The effect of incorporation of purified protein 4.1 into normal erythrocyte membranes is shown in Fig. 5. Increasing the concentration of protein 4.1 to $930 \mu \mathrm{g} / \mathrm{ml}$ did not change the stability of normal membranes. These data imply that entrapment of excess protein 4.1 into membranes that already have a normal complement of this protein cannot increase their stability. Furthermore, they also imply that specific interaction of protein 4.1 with membrane is necessary to restore stability to the deficient membranes.

In additional control experiments, the protein 4.1-deficient membranes were resealed in the presence of purified spectrin dimer $(620$ or $1,240 \mu \mathrm{g} / \mathrm{ml})$ and human serum albumin $(500$ or $1,000 \mu \mathrm{g} / \mathrm{ml}$ ). As shown in Fig. 6, both of these proteins produced minimal alterations in membrane stability. These observations show that neither an important erythrocyte skeletal protein nor a globular protein of approximately the same molecular weight as protein 4.1 can restore the stability of protein 4.1-deficient membranes.

SDS-PAGE analysis of reconstituted membranes. SDS-PAGE analysis confirmed the incorporation of protein 4.1 into reconstituted resealed ghosts. Purified protein 4.1 is primarily composed of two sequence-related polypeptides, protein 4.1a (80,000 $\mathrm{mol} \mathrm{wt}$ ) and protein $4.1 \mathrm{~b}(78,000 \mathrm{~mol} \mathrm{wt})$ (Fig. 7, left lane). With increasing amounts of added protein 4.1, the amount of protein 4.1 bound to the totally deficient membranes increased (Fig. 7, lanes 1-4). (Note that during the incubation of the ghosts at $37^{\circ} \mathrm{C}$ for $60 \mathrm{~min}$, some protein 4.1 degradation occurred, resulting in several new low molecular weight bands on gels.) The amount of the incorporated protein 4.1 was quantitated by performing the densitometric analysis on the dried gels. (We normalized the value of the amount of protein 4.1 by calculating the ratio of protein 4.1 to protein 4.2 , assuming that the amount of protein 4.2 was not altered during experiments.) In order to account for the interaction of protein 4.1 with the outer surface of the membrane, we also analyzed ghosts in which protein 4.1 was added after membrane resealing. These data are shown in lanes $l^{\prime}-4^{\prime}$ of Fig. 7 . The amount of protein 4.1 associated with membranes in these gels is thought to represent binding of the protein to the outside of the membrane. Subtraction of the amount of protein 4.1 in lanes $2^{\prime}-4^{\prime}$ from their counterparts in lanes 2-4 allowed us to estimate the amount of protein 4.1 associated with the inside of the ghost. The amount of protein 4.1 incorporated into the interior of protein 4.1-deficient erythrocyte ghosts was found to be three to five times more than the normal physiologic content of erythrocyte membranes. These data indicate that a significant amount of protein 4.1 is entrapped in
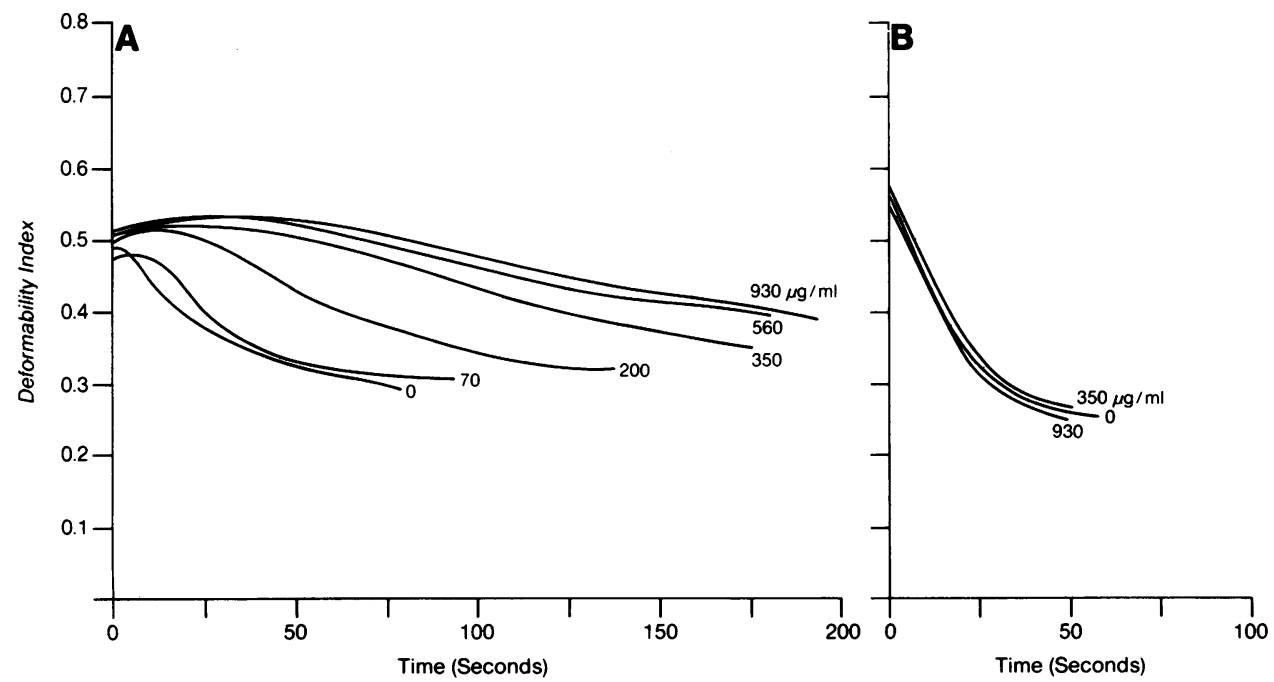

Figure 3. Restoration of membrane stability to erythrocyte ghosts totally deficient in protein 4.1. Ghosts prepared from totally deficient cells were incubated with $0,70,200,350$, 560 , and $930 \mu \mathrm{g} / \mathrm{ml}$ of protein 4.1 before resealing, and their membrane stability determined. Increasing the concentration of protein 4.1 resulted in a decrease in rate of fragmentation. Maximal restoration of membrane stability was seen at a protein concentration of $560 \mu \mathrm{g} / \mathrm{ml}$ (left panel). Addition of 350 and 930 $\mu \mathrm{g} / \mathrm{ml}$ of protein 4.1 after membrane resealing, followed by incubation at $37^{\circ} \mathrm{C}$ for $60 \mathrm{~min}$, did not alter the rate of fragmentation and hence membrane stability (right panel). 


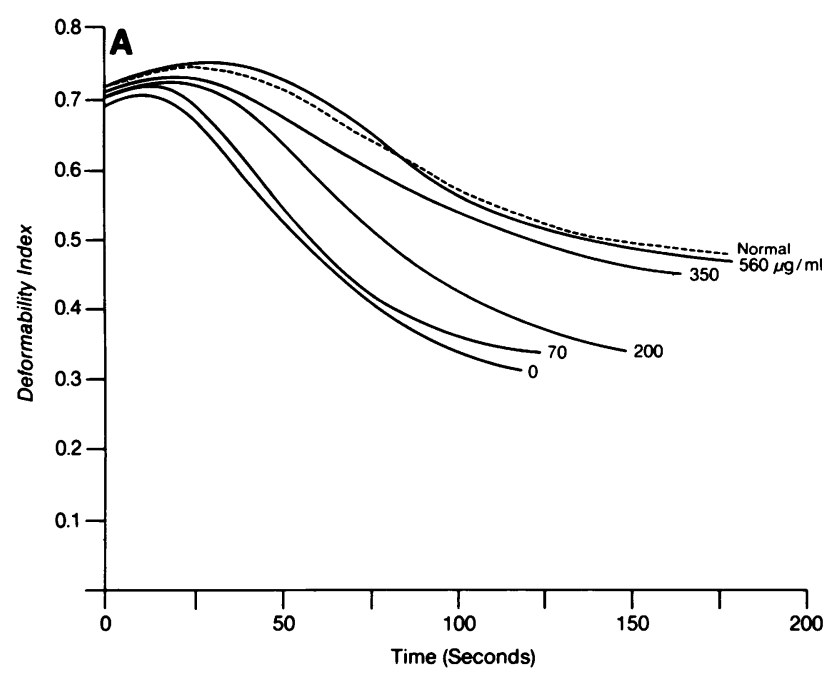

the interior of these ghosts. Similar data was also obtained using partially protein 4.1-deficient membranes.

In experiments with normal membranes, we also found that, with increasing concentrations of added protein 4.1, increasing amounts of the protein were found to be entrapped in the interior of these ghosts. Three to five times more than the physiological content of erythrocyte membrane was found to be incorporated into normal ghosts. However, in contrast to protein 4.1-deficient membranes, this excess protein 4.1 had no effect on membrane stability, as shown in Fig. 5. To determine if this incorporated protein 4.1 is closely associated with the membrane skeleton, washed and resealed membranes were treated with Triton $\mathrm{X}-100$. This treatment resulted in the reduction of membraneassociated protein 4.1 from three to five times the amount of normal to $<50 \%$ higher than normal content, suggesting that a large portion of the entrapped protein 4.1 is not tightly bound to the membrane skeleton. Similarly, in one experiment, treatment of reconstituted protein 4.1-deficient membranes with Triton X-100 resulted in a 50\% decrease in membrane-associated protein 4.1. This suggests that a fraction of the entrapped 4.1 tightly bound to the skeleton may be responsible for restoration of membrane stability.

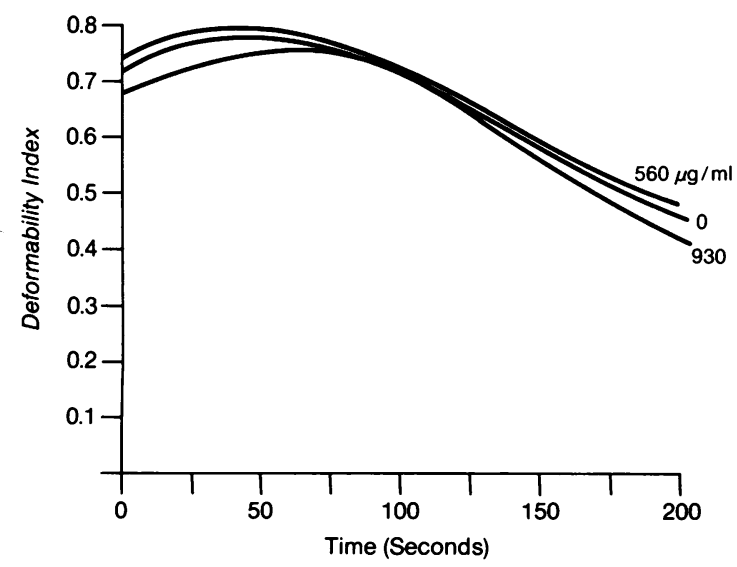

Figure 5. Membrane stability is unaltered by nonspecific binding of protein 4.1 to normal membranes. Normal erythrocytes were lysed, incubated with 0,560 , and $930 \mu \mathrm{g} / \mathrm{ml}$ of purified protein 4.1 , and resealed. The membrane stability was unaltered by the addition of purified protein 4.1 .

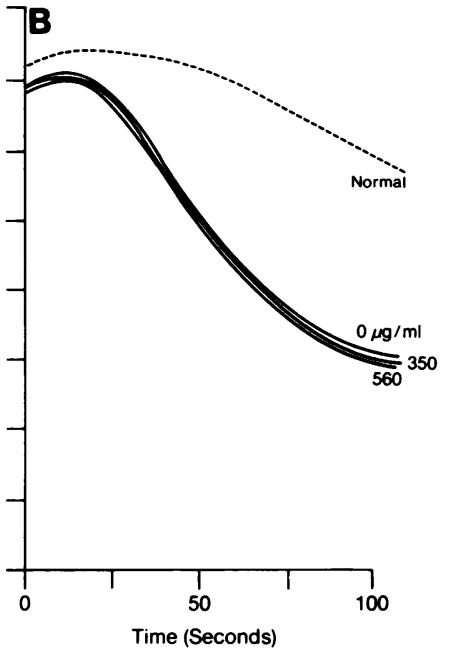

Figure 4. Restoration of membrane stability to partially protein 4.1 -deficient erythrocyte ghosts. Ghosts prepared from deficient cells were incubated with $0,70,200,350$, and 560 $\mu \mathrm{g} / \mathrm{ml}$ of protein 4.1 before resealing. Increasing the concentration of protein 4.1 resulted in a decrease in the rate of fragmentation. Membrane stability was restored to near-normal values at a protein concentration of $560 \mu \mathrm{g} / \mathrm{ml}(A)$. Addition of 350 and $560 \mu \mathrm{g} / \mathrm{ml}$ of protein 4.1 after reseal ing did not alter the rate of fragmentation and hence membrane stability $(B)$.

\section{Discussion}

Our ability to restore mechanical stability to unstable protein 4.1-deficient membranes by addition of the missing protein provides the most direct evidence that protein 4.1 has a direct effect upon membrane stability. The finding that protein 4.1 can restore membrane stability only when it has access to the cell interior implies that functional binding sites for this protein are localized in the cytoplasmic domain of the membrane. Furthermore, the finding that entrapment of excess protein 4.1 into normal membranes does not alter their stability implies that nonspecific association of protein 4.1 can have no effect on membrane stability. This further implies that the restoration of stability to deficient membranes must be through its functional association with other membrane components.

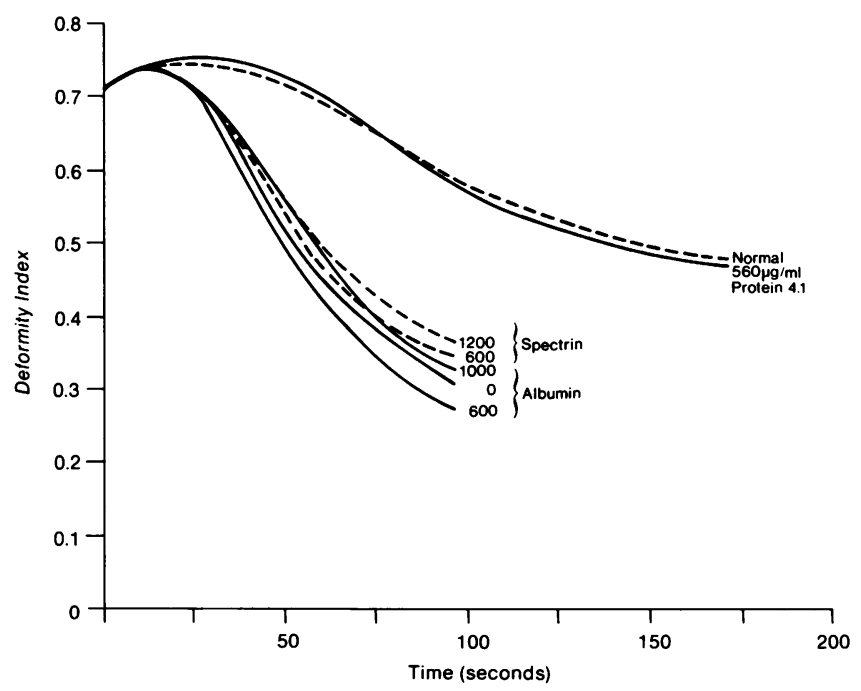

Figure 6. Membrane stability is unaltered by incorporation of spectrin and albumin into partially protein 4.1-deficient erythrocyte ghosts. Ghosts prepared from deficient membranes were incubated with 620 and $1,240 \mu \mathrm{g} / \mathrm{ml}$ of purified spectrin dimer and with 500 and 1,000 $\mu \mathrm{g} / \mathrm{ml}$ of human serum albumin. The membrane stability was minimally altered by the incorporation of either spectrin or human serum albumin. This is in contrast to restoration of membrane stability by added protein 4.1 . 


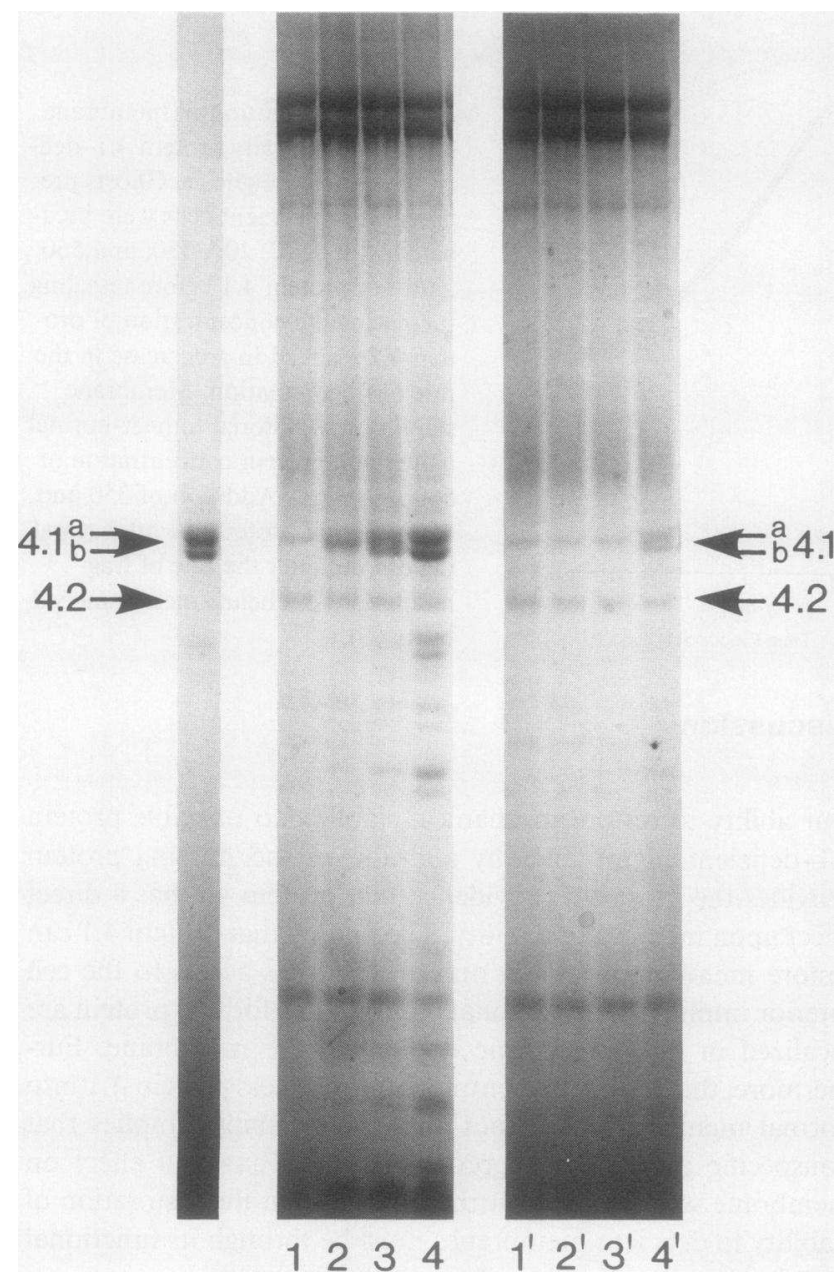

Figure 7. SDS-PAGE analysis of erythrocyte membranes totally deficient in protein 4.1 reconstituted with purified protein. Proteins $4.1 \mathrm{a}$ $(80,000 \mathrm{~mol} \mathrm{wt})$ and $4.1 \mathrm{~b}(78,000 \mathrm{~mol} \mathrm{wt})$, the principal constituents of the preparation used for reconstitution, are shown in the left lane. Minor amounts of polypeptides with molecular weights of 87,000 , 85,000 , and 67,000 can also be seen in this protein preparation. These polypeptides have previously been shown to be sequence-related to the principal constituents (39). Lanes $1-4$ are membranes that have been reconstituted with $0,200,560$, and $930 \mu \mathrm{g} / \mathrm{ml}$, respectively, of purified protein before resealing. After resealing, the membranes were washed with isotonic buffer to remove unbound protein 4.1 from the outside. The membranes were then relysed and washed with hypotonic buffer to remove unbound protein 4.1 from the cell interior. Addition of increasing concentrations of the protein resulted in increased amounts of protein 4.1 bound to the membrane. Lanes $l^{\prime}-4^{\prime}$ are membranes from ghosts to which $0,200,560$, and $930 \mu \mathrm{g} / \mathrm{ml}$, respectively, of purified protein 4.1 was added after resealing. After incubation at $37^{\circ} \mathrm{C}$ for $60 \mathrm{~min}$, they were washed and lysed as described above before analysis. Protein 4.1 bound to these membranes represents the interaction of added protein only with the outer surface of the membrane. Amounts of proteins $4.1 \mathrm{a}, 4.1 \mathrm{~b}$, and 4.2 shown by the arrows were quantitated by densitometric analysis.

Since protein 4.1 has been shown to modulate spectrin-actin interaction in vitro (19-21), it is likely that protein 4.1 maintains membrane stability through its ability to promote this interaction. Support for this molecular mechanism can also be inferred from the finding that erythrocytes from patients with hereditary spherocytosis in which a defective protein 4.1-spectrin association has been documented also show a reduction in membrane stability (15). Recently, protein 4.1 has also been shown to bind to inside-out erythrocytic residues from which protein 4.1, spectrin, ankyrin, and actin have been depleted (27). This finding has been used to suggest that protein 4.1 may link the skeleton to the lipid bilayer by association with integral membrane protein(s). At least three candidate proteins (glycophorin A [28], glycophorin C [29], and band 3 [30]) have been suggested for this binding. From our data, it is not possible to infer which of these biochemical interactions contribute to the restoration of membrane stability seen in the present study.

Although it is not surprising that the added protein 4.1 is able to physically bind to protein 4.1-deficient membranes, it is notable that this bound protein is able to restore a functional defect of the membrane. This implies that some of the bound protein 4.1 is able to integrate into the abnormal membrane skeletal organization and restore it to a more normal state of organization. It also suggests that the erythrocytic membrane skeleton is a dynamic structure into which missing skeletal protein components can be reintegrated even after it has been fully assembled on the membrane.

One previous study has also defined a functional role for a skeletal protein by incorporating the protein into deficient erythrocytes (31). This involved incorporation of spectrin into spectrin-deficient ( $s p h / s p h)$ mutant mouse erythrocytes. Reconstitution of spectrin by exchange hemolysis was shown to result in a partial correction of the instability of these cells. Generation of myelin figures and membrane lipid loss were used to document changes in cell stability.

Recently, protein 4.1-like polypeptides that react with antierythrocyte protein 4.1 IgG have been found in platelets, polymorphonuclear leukocytes, lymphocytes, fibroblasts, lens, and brain (32-38). However, the function of nonerythroid protein 4.1 has not yet been defined. The results of this study support a functional role for this protein in maintaining membrane mechanical stability in erythrocytes.

\section{Acknowledgments}

The authors would like to acknowledge the expert assistance of Mr. James Harris in the preparation of this manuscript. We would also like to thank the Bradai family for their cooperation.

This work was supported by grants AM16095, AM26263, and AM32094 from the National Institutes of Health.

\section{References}

1. Steck, T. L. 1974. The organization of proteins in the human red blood cell membrane. J. Cell Biol. 62:1-19.

2. Lux, S. E. 1979. Dissecting the red cell membrane skeleton. Nature (Lond.). 281:426-429.

3. Branton, D., C. M. Cohen, and J. Tyler. 1981. Interaction of cytoskeletal proteins on the human erythrocyte membrane. Cell. 24:2432.

4. Marchesi, V. T. 1983. The red cell membrane skeleton: recent progress. Blood. 61:1-11

5. Evans, E. A., and R. M. Hochmuth. 1977. A solid-liquid composite model of the red cell membrane. J. Membr. Biol. 30:351-362.

6. Mohandas, N., J. A. Chasis, and S. B. Shohet. 1983. The influence of membrane skeleton on red cell deformability, membrane material properties, and shape. Semin. Hematol. 20:225-242.

7. Liu, S. C., and J. Palek. 1980. Spectrin tetramer-dimer equilibrium 
and the stability of erythrocyte membrane skeletons. Nature (Lond.). 285:586-588.

8. Liu, S. C., J. Palek, J. Prchal, and R. C. Castleberry. 1981. Altered spectrin dimer-dimer association and instability of erythrocyte membrane skeletons in hereditary pyropoikilocytosis. J. Clin. Invest. 68:597-605.

9. Tchernia, G., N. Mohandas, and S. B. Shohet. 1981. Deficiency of skeletal membrane protein band 4.1 in homozygous hereditary elliptocytosis. Implications for erythrocyte membrane stability. J. Clin. Invest. 68:454-460.

10. Wolfe, L. C., K. M. John, J. C. Falcone, A. M. Byrne, and S. E. Lux. 1982. A genetic defect in the binding of protein 4.1 to spectrin in a kindred with hereditary spherocytosis. N. Engl. J. Med. 307:13671374.

11. Goodman, S. R., K. A. Shiffer, L. A. Casoria, and M. E. Eyster. 1982. Identification of the molecular defect in the erythrocyte membrane skeleton of some kindreds with hereditary spherocytosis. Blood. 60:772784.

12. Knowles, W. J., J. S. Morrow, D. W. Speicher, H. S. Zarkowsky, N. Mohandas, W. C. Mentzer, S. B. Shohet, and V. T. Marchesi. 1983. Molecular and functional changes in spectrin from patients with hereditary pyropoikilocytosis. J. Clin. Invest. 71:1867-1877.

13. Palek, J., and S. E. Lux. 1983. Red cell membrane skeletal defects in hereditary and acquired hemolytic anemias. Semin. Hematol. 20:189224.

14. Feo, C., S. Fischer, J.-P. Piau, M. J. Grange, and G. Tchernia. 1980. Premiere observation de l'absence d'une proteine de la membrane erythrocytaire (bande 4.1) dans un cas anemie elliptocytaire familiale. Nouv. Rev. Fr. Hematol. 22:315-325.

15. Mohandas, N., M. R. Clark, B. P. Heath, M. Rossi, L. C. Wolfe, S. E. Lux, and S. B. Shohet. 1982. A technique to detect reduced mechanical stability of red cell membranes: relevance to elliptocytic disorders. Blood. 59:768-774.

16. Mueller, T. J., and M. Morrison. 1977. Detection of a variant of protein 3, the major transmembrane protein of the human erythrocyte. J. Biol. Chem. 252:6573-6576.

17. Tyler, J. M., W. R. Hargreaves, and D. Branton. 1979. Purification of two spectrin binding proteins: biochemical and electron microscopic evidence for site-specific reassociation between spectrin and bands 2.1 and 4.1. Proc. Natl. Acad. Sci. USA. 76:5192-5196.

18. Goodman, S. R., J. Yu, C. F. Whitfield, E. N. Culp, and E. J. Posnak. 1982. Erythrocyte membrane skeletal protein bands 4 .1 a and b are sequence-related phosphoproteins. J. Biol. Chem. 257:4564-4569.

19. Ungewickell, E., P. M. Bennett, R. Calvert, V. Ohanian, and W. B. Gratzer. 1979. In vitro formation of a complex between cytoskeletal proteins of the human erythrocyte. Nature (Lond.). 280:811-814.

20. Fowler, V., and D. L. Taylor. 1980 . Spectrin plus band 4.1 crosslink actin. Regulation by micromolar calcium. J. Cell Biol. 85:361-376.

21. Cohen, C. M., and C. Korsgren. 1980. Band 4.1 causes spectrinactin gels to become thixotropic. Biochem. Biophys. Res. Commun. 97: 1429-1435.

22. Clark, M. R., and S. B. Shohet. 1976. Hybrid erythrocytes for membrane studies in sickle cell disease. Blood. 47:121-131. ${ }^{\bullet}$
23. Tyler, J. M., B. N. Reinhardt, and D. Branton. 1980. Associations of erythrocyte membrane proteins: binding of purified bands 2.1 and 4.1 to spectrin. J. Biol. Chem. 255:7034-7039.

24. Laemmli, U. K. 1970. Cleavage of structural proteins during the assembly of the head of bacteriophage T4. Nature (Lond.). 227:680-685.

25. Burnette, W. N. 1981. 'Western blotting': electrophoretic transfer of proteins from sodium dodecyl sulfate-polyacrylamide gels to unmodified nitrocellulose and radiographic detection with antibody and radioiodinated protein A. Anal. Biochem. 112:195-203.

26. Bessis, M., and N. Mohandas. 1977. A diffractometric method for the measurement of cellular deformability. Blood Cells. 3:209-221.

27. Shiffer, K. A., and S. R. Goodman. 1984. Protein 4.1: its association with the human erythrocyte membrane. Proc. Natl. Acad. Sci. USA. 81:4404-4408.

28. Anderson, R. A., and R. E. Lovrien. 1984. Glycophorin is linked by band 4.1 protein to the human erythrocyte membrane skeleton. Nature (Lond.). 307:655-658.

29. Mueller, T. J., and M. Morrison. 1981. Glycoconnectin (PAS2), a membrane attachment site for the human erythrocyte cytoskeleton. In Erythrocyte Membrane 2: Recent Clinical and Experimental Advances. W. C. Kruckenberg, J. W. Eaton, and G. J. Brewer, editors. Alan R. Liss, Inc., New York. 95-116.

30. Pasternak, G. R., R. A. Anderson, T. L. Leto, and V. T. Marchesi. 1985. Interactions between protein 4.1 and band 3: an alternative binding site for an element of the membrane skeleton. J. Biol. Chem. 260:36763683.

31. Shohet, S. B. 1979. Reconstitution of spectrin-deficient, spherocytic mouse erythrocyte membranes. J. Clin. Invest. 64:483-494.

32. Cohen, C. M., S. F. Foley, and C. Korsgren. 1982. A protein immunologically related to erythrocyte band 4.1 is found on stress fibers of non-erythroid cells. Nature (Lond.). 299:648-650.

33. Goodman, S. R., L. A. Casoria, D. B. Coleman, and I. S. Zagon. 1984. Identification and location of brain protein 4.1. Science (Wash. DC). 224:1433-1436.

34. Baines, A. J., and V. Bennett. 1984. Pig brain 4.1: identification and purification. J. Cell Biol. 99(4, pt. 2):300a. (Abstr.)

35. Spiegel, J. E., D. S. Beardsley, F. S. Southwick, and S. E. Lux. 1984. An analogue of the erythroid membrane skeletal protein 4.1 in nonerythroid cells. J. Cell Biol. 99:886-893.

36. Aster, J. C., M. J. Welsh, G. J. Brewer, and H. Maisel. 1984. Identification of spectrin and protein 4.1-like proteins in mammalian lens. Biochem. Biophys. Res. Commun. 119:726-734.

37. Davies, G. E., and C. M. Cohen. 1985. Platelets contain proteins immunologically related to red cell spectrin and protein 4.1. Blood. 65: 52-59.

38. Baines, A. J., and V. Bennett. 1985. Synapsin I is a spectrinbinding protein immunologically related to erythrocyte protein 4.1 . $\mathrm{Na}$ ture (Lond.). 315:410-413.

39. Goodman, S. R., K. Shiffer, D. B. Coleman, and C. F. Whitfield. 1984. Erythrocyte membrane skeletal protein 4.1: a brief review. In The Red Cell: Sixth Ann Arbor Conference. G. J. Brewer, editor. Alan R. Liss, Inc., New York. 415-439. 